\title{
Explicating Ways to Recollect Autobiographical Material During German-Language Biographical Interview
}

\author{
Larisa Rebrina*, and Nikolay Shamne \\ Volgograd State University, Department of Germanic and Romance philology, 40062 , pr. Universitetsky 100, Volgograd, Russia
}

\begin{abstract}
One of the subsystems of memory that is allocated from the bio-psychological and sociological points of view is autobiographical memory characterized by certain functional patterns. Autobiographical practices constitute socialized, culturally determined, materialized form of fixing autobiographical memory which is determined by memory mechanisms, communication laws and regulations. Their analysis allows making certain observations about the structural characteristics of autobiographical memory. Narration within biographical interviews is based on the interaction of the three forces (telling "I", being told "I" and coordinating their attitude "I") aimed at harmonizing the structures of life experiences and narrative structures, at the social acceptance of narration. This makes the implementation of the implicit principles of narrative associated with the structural elements of communication (the rules of integrity and completeness, dramatizing, explicitation). The autobiographical material in memory is constituted with "bright", "important", "crucial", "essential" events that correlate with the level structure of the memory subsystem. Revival of each of these types of autobiographical material in the biographical interviews under study is characterized by a certain specificity.
\end{abstract}

\section{Introduction}

Memory is an actively developed object of interdisciplinary research due to the importance, complexity and multidimensionality of the phenomenon operating at the levels of both society and individual. Memory and language are related in an intentional way through the method of organizing experience, the principle of semiosis and the type of environment. Like language, memory is characterized by a symbolic nature. The Iconic system of memory is formed by indexical, iconic signs, and signs-symbols that operate on the basis of references when the signified (the referent, that is, an event, thing, person, etc.) is replaced by the signifier [1]; and memories are referentially comparable with the verbal tropes (especially metaphor, metonymy, synecdoche), apply association and comparison [2].

Social, communicative nature, semiotic mechanisms of memory allow speaking about the cognitive potential of linguistics in this field and consistency in integrating existing interdisciplinary linguistic knowledge into the research memory paradigm [3], [4]. The range of discursive practices of memory, including autobiographical self-presentation, is constantly growing. One of the subsystems of memory that is allocated from the bio-psychological and sociological points of view is autobiographical memory performing its own functions and characterized by certain distinct patterns. Autobiographical memory (AM) assumes manipulating memories of personally meaningful events.
$\mathrm{AM}$ is a system of long-term, individual, declarative memory combining the characteristics of episodic and semantic subsystems, existing in the psychological chronotope, suggesting active adaptation to the social context, current needs and knowledge of the subject. Declarative memory as a separate subsystem is localized in the neocortex and constitutes semantic (the content includes general knowledge independent from the person) and episodic memory. Despite the distribution of memory functions between different brain zones, we can base on neuro-anatomical memory structures, that is, the contingency of individual forms of memory and certain parts of the brain (correlations are identified through clinical monitoring of patients with damaged brain parts and memory impairment). Thus, the AM can be allocated in terms of neuroanatomical structures as a separate subsystem characterized by a specific localization, the existence of specific brain structures responsible for the AM functioning (the temporal cortex, the right frontal area of the cortex). While the hippocampus is largely involved in episodic memory, the temporal lobes - in remembering general, conceptual events. AM plays a significant role in forming a personal identity as a result of socialization, individualization, combination of social identity (social roles internalized by individuals, experience of involvement in social groups) and self-identity [5], [6], [7]. Self-identity is formed through the personal identity (applying the knowledge about individual physical, behavioral, psychological characteristics) and the autobiographical

* Corresponding author: LNRebrina@ volsu.ru 
identity (experiencing unity and continuity of the stages of individual life stories) [8], [9].

\section{Methodology}

The analysis of autobiographical practices allows making important observations about the functional and structural characteristics of autobiographical memory (AM). Here we proceed from the following theoretical positions. AM exists in verbal (narrative) form and is characterized by attribution of the content as personal, characteristics of the temporary organization of material in memory, emotionally motivational and sociocultural conditionality. Autobiographical memory is governed by mutually reinforcing principles: the principle of correspondence (reflects the real experience) and the principle of coherence (correlates with other memories and self-vision of the individual) [10]. AM is a personal cognitive system governed by the actual needs of the subject; mediated through socio-cultural tools defining its macrostructure (real-life scenarios on the one hand, and narrative structures on the other hand); demonstrating its characteristic features in ontogeny (AM is formed when separating joint actualization as an inner psychic function and develops further as an intrapsychic phenomenon) [8], [11]. This subsystem is characterized by its own functional types of memory: pragmatic, self-regulatory, communicative, and existential [12]. Autobiographical practices constitute socialized, culturally determined, materialized form of fixing autobiographical memory which is determined by memory mechanisms, communication laws and regulations. The language, intermediating the formation and functioning of autobiographical memory, reorganizes preverbal events of the personal past through the concepts recorded with language means [7], [13], [14]. Episodic autobiographical memories are always perceived from a particular position or perspective (the subject-observer from the outside; the subject-actor as a participant of the event) and include details of the relevant sensory perception. Conceptual (semantic) memories are impersonal, affect long specific periods connected not through the time but thematically, and function as a scheme (the most generalized beliefs about oneself) [10], [15]. Thus, the episodic level of AM constitutes the events from the personal life history, and the semantic level is organized as schemes of subject's self-description at different time stages [14]. AM is characterized by certain ways of organizing the autobiographical material in memory, which include "bright", "important", "crucial" and "essential" events. It probably concerns semiotic mechanisms and correlation between these events and the life story of the subject, his "I-concept" to talk about the special indexicality of bright events (similarity of the signified and the signifier (the coherent image in memory)), the special indexicality of important and crucial events (a memory is a sign referring to the consequences of the events in the life of the subject; a memory is a sign referring to the two intervals of self-identity before and after the event); the special symbolism of essential events (a memory is a symbol of conceptualizing the personal essential qualities of the "I" self-image (first of all, mental and social)). The structure of the AM involves the following levels: 1) memories of specific episodes; 2) memories of crucial events; 3) vital topics; 4) a holistic view of one's fate [11].

The range of autobiographical self-presentations is very wide. One of them is the biographical interview which is a set of initiated statements of the subject, involving the organization of autobiographical experience in thematic and chronological sequence, the definition and reflection of the motives and goals of the regular personality characteristics. The empirical material for analysis was selected from German language files [7 - Deutsches Spracharchiv] and the Database of spoken German language [6 - Datenbank Gesprochenes Deutsch] at the Institute of German language (the city of Mannheim, IDS). The IDS archive brings together a variety of text corpus including scripts and audio in the literary language, various dialects and everyday spoken version of the language. Interactions differ in situational and social parameters. The material in text corpus is represented in the most "natural" form assuming minimal external impact, reflection of linguistic, both verbal and non-verbal (intonation, emphasis, etc.), and extralinguistic (sighs, pauses, laughter, coughing, etc.) information. This representation also facilitates interpretation of incomplete sentences, explication of modality and implicit meanings and statements [16]. One of the theoretical assumptions of the autobiographical narrative interview includes the everybody's potential intuitive competence of building the narrative (about the entire life, isolated event or life topics), so it should be socially acceptable and focused on the listener [17] and, thus, aimed at narrowing the gap between the experienced and narrated, narrative and structures of the experience [18], [19]. We also believe that the autobiographical experience is reproduced according to its importance for the subject-narrator; the narrative structure correlates with the structures of his life experience, and the subject of memories is the least prone to self-presentation in an unprepared statement [18], [20]; that these samples of the communicative practices are characterized by a tendency of the subject to completeness and integrity of the narrative, dramatizing (selective reproduction, orientation to subjectively meaningful autobiographical experiences due to the time frame of the interview), explicitation (a tendency to clarify the relationship, to explain), tendency to coherence, authenticity of reactualization of the autobiographical material (congruence of individual life history, personality, one's qualities) [18], [21], [22].

\section{Results}

Quantitative estimates selected for analyzing the biographical interviews indicate a predominant manifestation of re-actualized bright, occasional events $(65.1 \%)$, much less verbalizing memories of essential (16.3\%), important (13.9\%), crucial (4.7\%) events in the studied texts. Let us consider the examples of 
explicating the material memorizing forms in the studied interview.

\subsection{Bright event}

In the example of the initiated statement below, there is a re-actualized bright event of the autobiographical past. The reminiscing subject (50-year-old farmer) is telling ironically about his youth, how they were teenagers and gathered in their or one of the neighbouring villages (Gater, Mengersdorf, Hilbersdorf, Hausdorf, Gebbersdorf) to dance on Sundays. If their village did not have a dancing event, they gathered within a group of 3-4 people and rode bicycles. There were fights, and if the guests were few and could not resist, they quickly grabbed their bikes (as they had nothing else) and quickly went home. Next, the speaker describes a particular episode from his past when once he was in charge for cash (sold "tickets") at a dance party in his village and saw a stranger who did not want to pay (from Graze). He twice stopped him while dancing. But nothing came out of this. Then he grabbed the stranger at the back of the stranger's collar and flung to the door, and buddy Carl came up at that time and pulled the stranger off the ladder; it was so violent that the narrator thought the stranger was going to break his bones and neck. But the "guest" fortunately landed quite successfully. In a quarter of an hour, the stranger entered with his buddies, but the "owners" were stronger, more numerous, and outsiders had to leave in a hurry. It was their village, and they were young and extremely friendly, everybody defended each other and was fighting back if it came to fights.

Ach, am schönsten war's immer sonntags, wenn wir konnten tanzen gehen, getanzt habe ich gern, ich ging jeden Sonntag los zum Tanzen, und wenn bei uns nichts war, da gingen wir in Nachbardörfer, so Gater, nach Mangersdorf, nach Hilwersdorf oder nach Hausdorf, das waren so die Dörfer, wo wir am, auch in Gebbersdorf, da fuhren wir auch hin. Waren wir so immer drei, vier zusammen, die wir miteinander losfuhren, ist auch vorgekommen, dass wir uns das Leder vollgeklopft haben, wo wir dann mussten, dass wir dann mussten abhauen. Na ja, wurden schnell die Fahrräder geschnappt und ab, weg waren wir, wenn wir Leute, Kräfte genug waren, konnten wir uns ja zur Wehr setzen, aber das war mal nicht immer, haben wir einfach kehrtgemacht, die Fahrräder geschnappt, ab, weg waren wir, anderes hatten wir damals nicht, fuhren mit den Fahrrädern. ... Und bei uns einmal, da hatten wir auch einmal Tanzen. Ich hatte das Kasse, ich tat äh Tanzschleifen verkaufen, nun hatte ich einen, der bezahlte nicht, er war von Grase, und den hatte ich schon zweimal angehalten beim Tanzen, war nichts, und ich war so schlecht gelaunt. Da habe ich ihn von hinten an Kragen gefasst, rumgedreht und schupps zur Tür rausgeschmissen, und von draußen kommt der Karl, schnappt ihn und schmeißt ihn die Treppe runter. Ich dachte, er bricht sich Hals und Beine bis runter, aber er kam gut unten an, und der Enderfolg war, eine Viertelstunde drauf kam er mit seiner ganzen
Belegschaft, und da wollten sie uns den Saal ausräumen, aber wir waren ja mehr noch und stärker. Es kam nicht dazu, wir haben uns doch behauptet, denn wir waren uns in unserem Dorf, die jungen Kerle, verdammt einig, hatten ja bloß zwei Gasthäuser. Einmal gingen wir in das Gasthaus, einmal in das Gasthaus, aber wenn's Klopperei gab, von uns hat keiner was welche erwischt, wir waren uns immer einig, tat einer dem andern helfen (Interaktion OS126 [23]).

The status of the event being reproduced (occasional, bright) is indicated, for example, with the adverb 'einmal' and the use of evaluative conversational or familiar lexical units ('das Leder vollgeklopft haben' - to beat someone black and green; 'Klopperei'- fight, scuffle; 'abhauen' - to leave, ditch, to cut and run; 'verdammt' here - bloody, as hell, devilish; 'schnappen' grab, rake; 'schupps' (from 'der Schupp' - a kick) wham, pop, ready, etc; 'rausschmeißen' - to throw, to show the door; 'erwischen' - to catch, to grasp [24], [25]). Revival of the episode from the past includes the following components: spatial and temporal localization and content of the event, individual experiences and feelings of others / participants of the events. The subject of memories is constantly drawn to the description of his own feelings, motives, impressions and thoughts (e.g. 'am schönsten war's immer sonntags, wenn wir konnten gehen tanzen' - the best day was Sunday when we went dancing; 'ich jeden Sonntag ging los zum Tanzen' - I went dancing every Sunday; 'Ich dachte, er bricht sich Hals und runter Beine bis' - I thought he would break his neck, all the bones, etc.). The speaker fondly speaks of a sense of cohesion, friendliness of the young men in his village ('die jungen Kerle, verdammt einig' - young boys are absolutely friendly; 'immer wir waren uns einig' - we have always been friendly; 'wir haben uns doch behauptet, denn wir waren uns in unserem Dorf' - we won because we were in our village; 'tat einer dem andern helfen' - everyone came to rescue the other); this assessment reflects the value system of the narrator. The tone of the narrative is reflecting, ironic, nostalgic, with elements of emotional description. The implementation of an autobiographical narrative is based on the functioning of the three "I" which are: telling "I" (the subject of the story), being told "I" (the object of the story) and "I" that coordinates the relationship between the first "I" and second "I" [3]. The coordinating "I" appears in this case only in fallback touches, which reveal the congruent narrative (e.g., 'getanzt habe ich gern' - I loved dancing; 'wenn wir Leute, Kräfte genug waren, konnten wir uns ja zur Wehr setzen' - if we had many people and were strong enough, we could resist; 'ich war so schlecht gelaunt' - I was in such a bad mood, etc.). The telling "I" in the framework of the autobiographical narrative interview is evident in the efforts to relate the structure of life experience and story structure, following the principles formulated by $\mathrm{F}$. Schütze ("Zugzwange") [18], [19], [26] and ascending to the "postulates" or "maxims" by B. Lakoff and A. Greis: a) the integrity and completeness / Gestaltschließung (this particular episode gets a finished look, and it ends with a kind of generalization - "we were very close and always supported each other"; all relations are 
explicated); b) dramatizing / Kondensierungszwang (presentation of individually significant events and details); C) explicitation / Detailierungszwang (narrating the particular episode, the narrator clarifies the specific circumstances (temporal, spatial, causal) associated with this event (e.g., a commentary, preceding the narration of a specific episode, which the narrator considered Sundays especially beautiful because he and his buddies went dancing every Sunday either in the village or in neighbouring villages, that fights happened between newcomers and owners there; some mentioning when describing a particular episode that dancing was in the speaker's native village, that he was in a bad mood because a stranger did not want to buy a ticket to dance and did not leave the room). Throughout the narrative about the episode from the past, the speaker mainly focuses on his actions, feelings and not on the external circumstances, that is, maintains the position of the actor, the direct participant (enabled position). While describing the brightest occasional events during the biographical interview there are primarily implemented a reflecting $(28.2 \%)$ and inspired $(26.6 \%)$ modes, followed by emotional (16.1\%), nostalgic (14.5\%), ironic $(8.1 \%)$ and critical $(4.8 \%)$ modes. The object of recollections in most cases is positively evaluated.

\subsection{Important event}

In the following context, a 58-year-old man (the Director of the evening public University in Bochum) tells the story about a case happened at school, which determined his choice of profession and his passion for doing art. The described memory belongs to the so-called "startup memories" using the terminology by David Pillemer [27], involving the first, recognized as the earliest human experience in any meaningful area. The narrative about such an event was not plunged into the situational but the semantic context (the context of the life history) which is reflected in the ascendancy of speaker's interpretations: Ich selber bin als Schüler durch ein kleines Erlebnis eigentlich zur Kunstgeschichte gekommen. Ich war damals zwölf Jahre ungefähr alt, dreizehn Jahre, und auf einem königlich-bayerischen Gymnasium, humanistischen Gymnasium, wo's also noch sehr streng zuging, und eines Tages, in der großen Pause, sah ich unten in der Halle ein Bild hängen, ein Foto von dem Grabmal der Aegaeso, dieses wunderschöne Relief. Ich blieb davor stehen, obwohl eigentlich verboten war, während der Pause im Gebäude zu bleiben. Ich blieb davor stehen und war also wie gebannt, die Schönheit, der Rhythmus, diese wunderschöne Form an diesem Bild, die hat mich so hingerissen. Ich stand da eine ganze Weile, offenbar völlig versunken. Plötzlich legte sich eine Hand auf meine Schulter, und als ich mich umdrehte, schaute ich in die Augen unseres Direktors, der ein sehr gefürchteter Mann war. Ich kriegte einen furchtbaren Schreck und dachte, jetzt pfeift er mich an. Aber er guckte mich ganz sanft an und sagte: Komm mal mit. Ich ging mit ihm die Treppe hinauf, er nahm mich in sein Zimmer, und da schloss er einen Schrank auf und holte aus dem Schrank eine große Mappe, und in der
Mappe waren also lauter Fotos von griechischen Bildwerken. Und nun fing er an und zeigte mir dies und das und erzählte mir von seinen Reisen in Griechenland. Er selbst war klassischer Philologe und das war so eine so versunkene Stunde, dass wir beide, er und ich, das Schellen für den Anfang der Stunde überhört haben. Er guckte dann plötzlich auf die Uhr und sagte: Jetzt muss ich aber schnell in meine Klasse, du in deine, du kannst sagen, du wärest bei mir gewesen. Das hab ich dann auch getan, aber dieses Viertelstündchen hat einen solchen Eindruck auf mich gemacht, dass ich mit meinem ersten selbstverdienten Geld nachher hingegangen bin und habe mir ein Buch mit Bildern von griechischen Kunstwerken gekauft. Es war das erste Buch, was ich mir selber verdient hatte. Das steht heute noch in meiner, inzwischen sehr schönen, Bücherei. Das war der Anfang, und das ging dann eigentlich so weiter, dass ich mein Leben lang immer wieder wenigstens im Nebenfach mich mit Kunstgeschichte beschäftigt habe. Ich bin eigentlich Theologe. Und ich habe nachher auch später in meinem Bereich hier immer wieder kunstgeschichtliche Vorlesungen gehalten über alle Gebiete (Interaktion PF057 [23]).

Once, when the author studied at the Royal Bavarian humanitarian gymnasium in honour of Wilhelm, at the age of 12-13 years, during the break he saw on the lobby wall a picture of the tombstone relief that struck the schoolboy with its dynamism and beauty. The boy was mesmerized standing in front of the image, having forgotten about everything. The gymnasium had very strict rules. To stay inside the school building was prohibited during the break. Suddenly a hand touched him on his shoulder. It was the headmaster, a very strict and harsh man that scared many people. The young man was sure that he will be punished by the Director. But the Director invited him to his office, where he got an impressive folder out of the closet and began to show the pictures of Greek sculptures and told him a lot of fascinating stories about his trip to Greece. Both the student and the Director were so passionate that they missed the call to the lesson. The Director looked at his watch and said that he had to attend the class (he was a specialist in Classical Philology) and the boy had to go to his class, and if the teacher will blame the boy for being late, he can say that was at the Director's. This quarter of an hour greatly impressed the schoolboy, defined his interests and his passion for the art history. Having earned the first money, he bought a book with the works by the Greek masters. This marked the beginning of his passion for the art preserved for all his life. He became a theologian, but has always dealt with the art history and constantly lectured about the different types of art.

The significance of the event for the subsequent life history and its effects are reflected in the following descriptions: dieses Viertelstündchen hat einen solchen Eindruck auf mich gemacht; ich selber bin als Schüler durch ein kleines Erlebnis eigentlich zur Kunstgeschichte gekommen; das war der Anfang, und das ging dann eigentlich so weiter, dass ich mein Leben lang immer wieder ... mich mit Kunstgeschichte beschäftigt habe. In addition to the content of the events, 
the narrative includes a reference to the spatial and temporal localization (zwölf Jahre ungefähr alt, dreizehn Jahre; als Schüler; eines Tages, in der großen Pause; unten in der Halle; die Treppe hinauf; auf einem königlich-bayerischen Gymnasium, humanistischen Gymnasium; in sein Zimmer), experiences of the subject (hat mich so hingerissen; war also wie gebannt; dachte, jetzt pfeift er mich an; kriegte einen furchtbaren Schreck; war so eine so versunkene Stunde) and the other participant of the event (und sagte: Jetzt muss ich aber schnell in meine Klasse, du in deine, du kannst sagen, du wärest bei mir gewesen; das war so eine so versunkene Stunde, dass wir beide, er und ich, das Schellen für den Anfang der Stunde überhört haben); description of the effects of the event, introduction into the context of the life history (war der Anfang, und das ging dann eigentlich so weiter, dass ich mein Leben lang immer wieder wenigstens im Nebenfach mich mit Kunstgeschichte beschäftigt habe; hat einen solchen Eindruck auf mich gemacht, dass ich mit meinem ersten selbstverdienten Geld nachher hingegangen bin und habe mir ein Buch mit Bildern von griechischen Kunstwerken gekauft; durch ein kleines Erlebnis eigentlich zur Kunstgeschichte gekommen). The narrator concentrates on his own feelings and experiences. The narrative is built, primarily, from the perspective of the author-actor. The subject of memories uses the evaluative, emotional language. The lexical units with positive semantics ('das wunderschöne Relief'- a great relief; 'wie gebannt' - captivated, charmed; 'die Schönheit' - the beauty; 'wunderschöne Form' - a beautiful form; 'hinreißen' - to delight, to captivate, to enthrall, to fascinate; 'ganz sanft angucken' - to look at someone in a good, gentle manner and with warmth; 'völlig versunken' - fully immersed, fascinated; 'sehr schön' - very nice) take precedence over the lexical units with negative evaluation of the object of nomination ('sehr streng' - very strict; 'gefürchtet' - fear-inducing; 'ein furchtbarer Schreck' - horror, awful fright; 'anpfeifen' - to chide, to scold) [24]. The narrator realizes inspiring and reflecting tones. The analyzed context also illustrates the interaction between the told and telling "I", followed implicit principles of narrative in the biographical interviews: a) the integrity and completeness (the episode is placed in a closed-in construction, is introduced through a statement establishing its status as a major event, fixing the event into the context of the narrator's life history, ends with a reference to "sustainable" consequences throughout later life; and reveals the impact of the event on the told "I"); b) dramatizing (reporting individually significant information); C) explicitation (specifying the spatial, temporal, causal circumstances: for example, the narrator notes that the rules in the gymnasium was strict and he accidentally broke them, that everybody was afraid of the Director, to explain why he expected troubles from the Director and was scared; points what attracted him in the relief; mentions that the Director was a specialist in Classical Philology - the complex of sciences about the literary heritage of Ancient Greece and Rome - that explains his interest in Greece; says that the first book they bought was a book on Greek art to make the effect of the event more obvious). When re-actualizing important events in biographical interviews the most relevant mode is a reflecting mode $(60.9 \%)$, less common are encouraged $(13 \%)$, emotional $(8.7 \%)$, nostalgic $(6.5 \%)$, vain $(6.5 \%)$ and critical $(4.3 \%)$ mode of narration.

\subsection{Essential event}

These events are mainly bound with personal meaning and elaborated (e.g., compared to bright events), important for the formation of "I-concept" reflecting the essential characteristics of personality or the personal image of "I", and can cover quite a long period of the subject's life. The data of memories in a concentrated symbolic form reflect life aspirations, goals, motives, character traits of the subject (cf. "memories-anchors" by David Pillemer [27]). In the context of biographical interviews a 48-year-old roofer talks about his career path within his profession, professional growth, attitudes and motives, comprehending and formulating an important quality (not to be afraid to face difficulties, to gain knowledge, to take on new challenges, to strive for the goals, not to follow easy ways), which, according to him, is inherent to him, determined his life allowing him to achieve much: Ich selber habe meinen Beruf eine große Zeitlang meines Lebens verflucht, wenn ich so sagen soll. Ich habe in Buchholz, Kreis Harburg, ungefähr dreißig Kilometer von hier, gelernt. Ich wurde als Waisenkind dort hingeschickt bei voller Kost. Und wenn ich dann in der Gewerbeschule mich mal umguckte, dann hatten die andern alle Schlips und Kragen um bei ihre Berufe als kaufmännischer Verkäufer in der Textilabteilung; na, jeder versuchte, möglichst von der schweren Handarbeit, die auch schmutzig ist, wegzugehen. Und als Geselle spürte ich das denn ganz besonders hart, wenn man von morgens bis abends die Dachziegel immer rauf und runter. Aber jetzt, wo man Meister ist und aus ein Haufen Dachziegel ein Werk formen kann, und selbst entscheiden kann, welche Arbeit man annehmen will; ich habe sehr viel Kirchen Hamburgs, in ganzen siebzehn Kirchen und sieben Türme, in den letzten zwölf Jahren gedeckt, darunter auch in Hamburg die Hauptkirche, Jakobikirche in der Steinstraße und die Katharinenkirche am Dovenfleet. In jedem Falle liegen dreiundfünfzigtausend Dachziegel auf so ein Dach, insgesamt dreitausend Quadratmeter jedes Dach. Und jetzt, wo ich als selbständiger Meister über alles selber leiten und fungieren kann, liegt eine gewisse Freude dadrinne, wenn man ein vollendetes großes Werk in Form einer gewaltigen Kirche fertigstellen kann. Da gehört auch viel Denken zu und Vorkalkulieren und Einteilen der Leute, und man muß bei dreißig Mann, wie ich seinerzeit beschäftigte vor sieben Jahre, verdammt Menschenkenntnisse haben; der eine, der kann das vertragen, dass man ihn mit "Du" anredet und ihn in groben Ton anspricht, und der andere will wieder ganz fein angesprochen werden. Es gehört 'n Fingerspitzengefühl dazu, was wohl alles insgesamt eben den Meister ausmacht und die Erfahrung. Und dieses 
Meister-sein-dürfen oder Meister-werden wollen, das Streben danach hin, das ist, glaub ich wohl, das einzigste Ziel. Ich kenne viele Gesellen, mit denen ich früher in Firmen als Gesellen gewesen bin hier in Harburg, die sind abgewandert in den Fabriken. Der große Wurf, sich hinzusetzen und sich auf die Meisterprüfung vorzubereiten, dazu hatten sie die Kraft nicht. Sie sind dann den einfachen Weg gegangen und sind irgendwie kleine Abteilungschef in Fabriken geworden (Interaktion PF024 [23]).

In the beginning, the narrator hated his profession for quite a long time. It happened that he had not chosen it and was just sent to the appropriate school (Buchholz, Harburg district) on the full allowance as an orphan. In the vocational school, all students wanted to be sellers in the textile department, no one wanted to provide dirty physical labour. Being an apprentice, he was forced to drag tiles up and down from morning till evening and felt all the burden of his profession. But now, having become a master, when he can make a roof out of a handful of shingles and decide for himself what job to take up after he has made the roofs for seventeen churches and seven towers in Hamburg for the last twelve years, including the town's main Church, the Church of St. Jacob in Steinstraße, Catherine Church in Dovenfleet (53 thousand tiles on every roof; a 3,000 $\mathrm{m}^{2}$ each roof), his feelings, evaluation and self-assessment have changed, now he is happy and proud of the results he has achieved. As a master he is in charge for everyone, needs to know and be able how to calculate, to estimate, to allocate people (sometimes he had up to 30 people under his supervision), and to understand people. These are intuition, instinct and experience which made a specialist become a craftsman. He had a goal to become a master so he became in contrast to those apprentices whom he worked together with in Hamburg, who were not strong enough to prepare for exams to become a master, who chose an easier way.

This memory forms an important part of the narrator's perception of himself, his purpose and his personality. The basis of the narrative is a reflection about his own goals, motives, success and distinguishing features. An accompanying mode is the mode of satisfaction (the narrator is happy with himself). There are explicated the temporal, spatial and causal relations (e.g., the narration thoroughly demonstrates and explains the change in the attitude of the speaker to the profession). As it is shown by the analysis, when demonstrating autobiographical events from the past the prevailing modes are reflecting $(6 \%)$ and inspired $(26.3$ $\%)$, less relevant modes are emotional $(18 \%)$, vain $(8.2$ $\%)$, nostalgic $(1.6 \%)$.

\subsection{Crucial event}

In the following analyzed extract of the biographical interview below, the respondent (21-year-old female student) tells about a crucial event happened in school years (relocation of her family to the Rhineland region), which influenced the character of the woman, her behavioral stereotypes and self-perception besides other things: In den ersten sechs Jahren war es sehr schwierig für mich, dadurch, dass die Rheinländer eine ganz andere Mentalität haben und ich eigentlich mehr die westfälische Art von meiner Mutter geerbt habe, wurde ich nicht richtig warm. Ich war immer als sehr schüchtern bekannt. Aber ich sagte mir dann, als ich sechs Jahre nun auf der Schule war, dass sich das ändern müsse, bin etwas mehr aus mir heraus gegangen, und man meint heute, dass ich doch mehr ein rheinischer Typ sei. Ich war hinterher Klassensprecherin und, wie man so sagt, spielte so etwas die erste Geige. Ja, und muss sagen, dass ich mich in den letzten drei Jahren sehr gut mit meinen Mitschülerinnen verstanden habe (Interaktion PF035 [23]). - In the first six years, it was very difficult for me due to the fact that the inhabitants of the Rhineland region have a completely different mentality, and I'm more like my mother who was a native of Westphalia, so I have never been particularly warm to others, was always very shy. But I told myself after I had already spent six years in a local school that this had to be changed, so I became more open; today they say that I am rather of a "Rhenish" type. Subsequently, I became the head of the class, and, as they say, was the first violin. Oh, and I must say that in the past three years, I have had very good relationships with my classmates [28], [29].

The young girl tells that she had to adapt to the conditions changed, to meet new people, to become a girl next door for them, and that made her change. The respondent describes her feelings, thoughts and motives of actions (und ich eigentlich mehr die westfälische Art von meiner Mutter geerbt habe; wurde ich nicht richtig warm; war immer als sehr schüchtern bekannt; war es sehr schwierig für mich, dadurch, dass die Rheinländer eine ganz andere Mentalität haben; muss sagen, dass ich mich in den letzten drei Jahren sehr gut mit meinen Mitschülerinnen verstanden habe; ich sagte mir dann, ... dass sich das ändern müsse; man meint heute, dass ich doch mehr ein rheinischer Typ sei). The narrator positively estimates her actions and the resulting changes (Ja, und muss sagen, dass ich mich in den letzten drei Jahren sehr gut mit meinen Mitschülerinnen verstanden habe). The narrative includes description of the "character" before her adaptation (nicht richtig warm, schüchtern, andere Mentalität) and after it (bin etwas mehr aus mir heraus gegangen, die erste Geige spielte, Klassensprecherin, gut mit meinen Mitschülerinnen verstanden habe), comparison of two self-descriptions. The mode of the narrative is reflecting, with the elements of satisfaction mode. The analyzed example also illustrates the previously described principles of integrity and completeness, dramatizing and explicitation; the narrative is built mainly from the position of the subjectactor. Elaboration of the memories is primarily focused on the establishment of intervals of self-identity, periodization of the life stages and key moments of individual development, as well as comprehension of own cultural self-identification. Narration of crucial events in the biographic interview corresponds with the predominant implementation of the reflecting mode (50 $\%$ ), followed by emotional $(22.2 \%)$, vain (16. $7 \%$ ), inspiring $(5.6 \%)$ and critical $(5.6 \%)$ of modes. 


\section{Conclusion}

Biographical interviews often manifest bright, occasional, less often essential, important and crucial events from the individual past. Revival of autobiographical memory in the biographical interview involves functioning of the three "I": telling "I", told "I" and "I" that coordinates the relationship between the first "I" and the second "I". The telling "I" in the framework of the studied narratives appears in the efforts of the subject to relate the structure of life experience and the story structure, to follow the principles of integrity, completeness, dramatizing and explicitation. When reactualizing all forms of the autobiographical material in the studied interviews, we attract the prevailing reflecting, emotional and inspired modes. In this case, the subject often focuses on his own experiences and feelings (memories are represented through the prism of his perception - the enabled position), not on the external circumstances (position of the observer). Manifestation of a bright event is dynamic, emotional description, compulsory reproduction of temporal and spatial characteristics of the situation. The narrative includes forming a coherent picture of the event, an emotional-semantic interpretation often limited by the past. Applied emotional vocabulary indicates unusual impressions and experiences of the subject. Reactualization of important events in the biographical interview involves understanding their consequences, their role in the life history of the individual, correlation with the vital topic and emotional experience of the connection between a fragment of the past and the current situation, actual motives and the needs of the subject. The description is organized as a flashback from the present day. The temporal perspective is determined by the subjective localization of the event on the axis of personal history and can cover a relatively large thematically unified time intervals. In biographical interviews, reactualization of the essential events as a certain symbol, a synthesis, a congruent metaphor of the identity include the verbalized experiences of the identity, correlation of the characteristics of the events and persons implemented through the language possessing attribute and evaluative semantics. When recollecting crucial events, description of memories is built as a reflection that maps two self-descriptions, as a subjective evaluation of changes, their impact and relations to the current motives and needs of the individual. The focus of the narrative usually covers the subject himself. The temporal perspective is divided into two dimensions ("before" and "after" the event), objectifying continual intervals of self-identity of the person.

\section{References}

1. Revzina, criti. and sem 10, 10-24 (2006)

2. N.G. Bragina, Mem. Discour. Mechan. of recollect. URL:

http://www.russian.slavica.org/article6036.html (date of access: 16.03.18)
3. L.N. Rebrina, E.Yu. Malushko, Advances in Social Science Education and Humanities Research (ASSEHR) 97, 233-238 (2017)

4. L.N. Rebrina, A.A. Petrova, Tomsk State Univ. Jour. 420, 66-73 (2017)

5. A.D. Baddeley, Theoretic. Perspect. on autobiograph., Mem., 13-29 (1992)

6. M.A. Conway, D.C. Rubin, Theo. of mem., 103-137 (1993)

7. A. Lindemann, Europ. Jour. for psychoanal. ther. and res. selbstpsychol. 24, 7 (2006)

8. V.V. Nurkova, The world of psychol 2(38), 77-86 (2004)

9. E. Yu. Malushko, International Multidisciplinary Scientific Conferences on Social Sciences and Arts, 1155-1160 (2015)

10. V.V. Blagutina, La Recher, 7-8 (2009), URL: http://www.inauka.ru/analysis/article96468/print.ht ml (date of access: 16.03.18)

11. V.V. Nurkova, Cult.-hist. psychol. 1, 17-26 (2008)

12. K.N. Vasilevskaya, Indi.-typol. feat. of autobiogr. mem.: PhD thesis (2008)

13. H. Löfller, The past in or. tradit., 100-113 (1988)

14. K. Nelson, Journ. of narr and life hist. 1, 2-3, 109127 (1991)

15. E. Korobova, I. Kardovich, D. Mironova, M. Konysheva, Advances in Social Science Education and Humanities Research (ASSEHR) 97, 119-124 (2017)

16. H. Hermanns, Handbuch Qualitat. Sozialforsch., 182-185 (1991)

17. R. Bonsack, Rekonstr. Sozialforsch (1991)

18. F. Schuetze, New pract. 3, 283-293 (1983)

19. F. Schütze, Biogr. and soc. real., 78-117 (1984)

20. S.V. Serebryakova, A.I. Milostivaya, Vestnik Volgogradskogo Gosudarstvennogo Universitetaseriya 2-yazykoznanie 16 (3), 48-57 (2017)

21. G. Lucius-Hoene, A. Deppermann, Reconstruct. narr. ident (2004)

22. V.F. Zhuravlev, Sociol. 3, 34-43 (1993)

23. DSAv - Deutsch. Spracharch, URL: http://dsavoeff.ids-mannheim.de/DSAv (date of access: 16.03.18)

24. DUD - „Dud. online”, URL: https://www.duden.de (date of access: 16.03.18).

25. DWDS - „The dig. diction. of the Germ. lang.”, URL: http://www.dwds.de (date of access: 16.03.18)

26. D.Yu. Gulinov, M.R. Zheltukhina, L.A. Shestak, G.G. Slyshkin, V.V. Katermina, L.D. Chervyakova, Modern Journal of Language Teaching Methods 8 (2), 159-173 (2018)

27. D.B. Pillemer, Rev. of gen. psychol. 5(2), 123-134 (2001)

28. M.A. Suzdalova, V.G. Lizunkov, E.Yu. Malushko, N.A. Sytina, V.E. Medvedev, The European 
Proceedings of Social \& Behavioural Sciences EpSBS, XIX, 450-455 (2017)

29. A. Dolzhikova, V. Kurilenko, Yu. Biryukova, N. Pomortseva, O. Shcherbakova, SGEM International Multidisciplinary Scientific Conference on Social Sciences and Arts, 371-379 (2016) 